FEDERAL RESERVE BANK OF SAN FRANCISCO

WORKING PAPER SERIES

\title{
The Determinants of Household Saving in China: A Dynamic Panel Analysis of Provincial Data
}

\author{
Charles Yuji Horioka \\ Institute of Social and Economic Research, Osaka University, \\ and \\ National Bureau of Economic Research, Inc. \\ Junmin Wan \\ Osaka School of International Public Policy, Osaka University
}

January 2007

Working Paper 2007-28

http://www.frbsf.org/publications/economics/papers/2007/wp07-28bk.pdf

The views in this paper are solely the responsibility of the authors and should not be interpreted as reflecting the views of the Federal Reserve Bank of San Francisco or the Board of Governors of the Federal Reserve System. This paper was produced under the auspices of the Center for Pacific Basin Studies within the Economic Research Department of the Federal Reserve Bank of San Francisco. 


\title{
THE DETERMINANTS OF HOUSEHOLD SAVING IN CHINA:
}

\section{A DYNAMIC PANEL ANALYSIS OF PROVINCIAL DATA*}

\author{
Charles Yuji Horioka** \\ Professor, Institute of Social and Economic Research, Osaka University, and \\ National Bureau of Economic Research, Inc. \\ horioka@iser.osaka-u.ac.jp \\ and \\ Junmin Wan
}

Research Associate, Osaka School of International Public Policy, Osaka University wan@osipp.osaka-u.ac.jp

January 6, 2007

*We are grateful to Hideki Hayashi, Takako Fujiwara-Greve, Teh-Ming Huo, Insang Hwang, Shinsuke Ikeda, Junichiro Ishida, Miki Kohara, Justin Yifu Lin, Ronald I. McKinnon, Kazuo Ogawa, Hugh Patrick, Masaya Sakuragawa, Shizuka Sekita, Katsuya Takii, Midori Wakabayashi, Xiaoping Wang, Calla Weimer, Tongsheng Xu, Zhihao Yu, Yaohui Zhao, and especially Christopher Carroll, Louis Kuijs, Colin McKenzie, Masao Ogaki, and Etsuro Shioji, and participants of the Seoul Conference on "China and Emerging Asia: Reorganizing the Global Economy," the Seattle Conference of the Asia-Pacific Economic Association, the Summer Institute of the National Bureau of Economic Research, and the fall meeting of the Japanese Economic Association, seminars at the Osaka School of International Public Policy (OSIPP ) of Osaka University, the Asian Public Policy Program of Hitotsubashi University, the China Center for Economic Research of Peking University, the School of Economics of Jiangxi University of Finance and Economics, and the Faculty of Economics of Keio University for their valuable comments, and Horioka is grateful to the Ministry of Education, Culture, Sports, Science and Technology of the Japanese Government for Grant-in-Aid for Scientific Research number 18330068, which supported this research.

**Address for correspondence: Charles Yuji Horioka, Institute of Social and Economic Research, Osaka University, 6-1, Mihogaoka, Ibaraki, Osaka 567-0047, JAPAN Tel.: 81-6-6879-8586, Fax: 81-6-6878-2766, Email: horioka@iser.osaka-u.ac.jp

Forthcoming in Journal of Money, Credit and Banking (accepted December 20, 2006). 


\begin{abstract}
In this paper, we conduct a dynamic panel analysis of the determinants of the household saving rate in China using a life cycle model and panel data on Chinese provinces for the 1995-2004 period from China’s household survey. We find that China’s household saving rate has been high and rising and that the main determinants of variations over time and over space therein are the lagged saving rate, the income growth rate, and (in some cases) the real interest rate and the inflation rate. However, we find that the variables relating to the age structure of the population usually do not have a significant impact on the household saving rate. These results provide mixed support for the life cycle hypothesis as well as the permanent income hypothesis, are consistent with the existence of inertia or persistence, and imply that China's household saving rate will remain high for some time to come.

Journal of Economic Literature classification numbers: D12, D91, E21, J10.

Key words: Age structure, China, demographics, dependency ratio, habit formation, household saving, household saving rate, household, inertia, life cycle hypothesis, life cycle model, permanent income hypothesis, persistence, saving, saving rate.
\end{abstract}




\section{Introduction}

China has attracted increasing attention because it is the world's most populous nation and because it has maintained phenomenal rates of economic growth in recent years. For example, the Asian Development Bank now projects that China will attain a growth rate in excess of 9\% in 2006 for the fifth consecutive year, thereby serving as the engine of growth in the Asian-Pacific region (Nihon Keizai Shimbun, evening edition of April 6, 2006, page 1).

Moreover, another reason for being interested in China is that China introduced a so-called "one-child policy" in 1979 as a way of controlling population growth. This is an interesting natural experiment that makes fertility largely exogenous and enables us to assess the impact of the age structure of the population on the household saving rate without worrying about endogeneity issues. Moreover, because the one-child policy was applied more leniently to ethnic minorities, the policy also led to substantial variations among provinces in the age structures of their populations, and this will enable us to more sharply estimate the impact of the age structure of the population on the household saving rate.

Yet another noteworthy aspect of China's economy is its high saving rate. China has had by far the highest overall saving rate in the world since at least 2000, and her saving rate has increased even further since 2000 — to nearly 50\% of GDP. Gross capital formation (investment) is also high in China, but because saving exceeds investment, China has been running a net saving surplus, which translates into a current account surplus, and that surplus has been growing sharply--from 1.9\% of GDP in 2000 to $3.6 \%$ in 2004 and a remarkable $7.2 \%$ in 2005--even though China is investing at a staggering rate of $43-46 \%$ of GDP and even though China is still relatively poor. This 
has made China one of the world's largest capital exporters and has exacerbated trade frictions with the United States and other countries. Moreover, China's net saving surplus shows no signs of abating (The Economist, September 24-30, 2005, edition, page 13 of “A Survey of the World Economy”). ${ }^{1}$ Thus, it is important to understand the determinants of, and future trends in, China's saving rate, and the obvious candidates are the rapid rates of economic growth alluded to earlier and the age structure of the population, which has shown tremendous variation over time as well as over space.

In this paper, we conduct a dynamic panel analysis of the determinants of the household saving rate in China using a life cycle model and panel data on Chinese provinces for the 1995-2004 period from China’s household survey.

At least two previous studies have conducted similar analyses. Kraay (2000) uses panel data on Chinese provinces from China's household survey to analyze the determinants of the saving rates of rural and urban households during the 1978-83 and 1984-89 periods and finds that, in the case of rural households, future income growth has a negative and significant impact on their saving rates, that the share of food in total consumption has a negative and significant impact on their saving rates, presumably because households closer to the subsistence level have less ability to save, and that neither the dependency ratio (proxied by the ratio of population to employment) nor future income uncertainty has a significant impact on their saving rates. However, Kraay (2000) finds that virtually none of the explanatory variables has a significant impact on the saving rates of urban households. Modigliani and Cao (2004) conduct a regression analysis of the determinants of the household saving rate using times series data for the 1953-2000 period and find that the long-term growth rate, the reciprocal of 
the dependency ratio (proxied by the ratio of the employed population to the number of minors), the deviation of growth from the long-term growth rate, and inflation all have positive and significant impacts on the household saving rate. Thus, the two studies obtain somewhat conflicting results. Kraay (2000) finds that the dependency ratio does not have a significant impact on the household saving rate, whereas Modigliani and Cao (2004) find that it does. Moreover, Kraay (2000) finds that future income growth has a negative and significant impact on the household saving rate, whereas Modigliani and Cao (2004) find that the long-term growth rate and the deviation of growth from the long-term growth rate have a positive and significant impact on the household saving rate.

The current study improves upon these earlier studies in a number of respects: (1) the data are much newer, (2) the dependent variable (the household saving rate) is defined more carefully and includes household investments in real assets, (3) the dependency ratio is defined more carefully and the young dependency ratio and the old dependency ratio are entered separately, (4) we include variables not included by previous authors such as the lagged saving rate and the interest rate, (5) we obtain results for the sample of urban households, the sample of rural households, the sample of all households, and a pooled sample of urban and rural households (unlike Kraay (2000), who obtains results only for urban and rural households, and Modigliani and Cao (2004), who obtain results only for all households), and (6) we use superior estimation techniques.

This paper is organized as follows: In section 2, we present data on household saving rates and related variables; in section 3, we discuss the estimation model and data sources; in section 4, we discuss the estimation method; in section 5 , we present the 
estimation results; and section 7 is a concluding section.

To preview our main findings, we find that China's household saving rate has been high and rising and that the main determinants of variations over time and over space therein are the lagged saving rate, the income growth rate, and (in some cases) the real interest rate and the inflation rate. However, we find that the variables relating to the age structure of the population usually do not have a significant impact on the household saving rate. These results provide mixed support for the life cycle hypothesis as well as the permanent income hypothesis, are consistent with the existence of inertia or persistence, and imply that China's household saving rate will remain high for some time to come.

\section{Data on Saving Rates and Other Related Variables}

In this section, we present data on household saving rates and other related variables.

First, Figure 1 shows data on trends over time in the age structure of the population during the 1949-2004 period, and as can be seen from this figure, there have been pronounced trends in both the young dependency ratio (the ratio of the population aged 0-14 to the population aged 15-59) and the old dependency ratio (the ratio of the population aged 60 or older to the population aged 15-59). The former increased from 0.57 in 1950 to 0.77 in 1964 before starting to decline, falling to 0.28 by 2004 (due in large part to the "one-child policy” and other population control measures), while the latter increased more or less steadily from 0.13 in 1950 to 0.18 in 2004 . Finally, the total dependency ratio (the ratio of the population aged $0-14$ or 60 or older to the population aged 15-59) showed more or less the same trends over time as the young 
dependency ratio, increasing from 0.70 in 1950 to 0.89 in 1964 before starting to decline, falling to 0.46 by 2004 (also due in large part to the "one-child policy" and other population control measures). The life cycle hypothesis predicts that the age structure of the population will have a significant impact on the saving rate and in particular that the dependency ratios will have a negative impact on the saving rate, and if we compare trends over time in the national saving rate with trends over time in the dependency ratios, the upward trend in the saving rate that has been observed since the 1960s coincides with a downward trend in the young and total dependency ratios during the same period, suggesting that the latter may be a cause of the former.

Looking next at the age structure of China's population in international comparison, China's young dependency ratio was higher than the worldwide level in 1975 (0.74 vs. 0.67) but fell at an unprecedented rate due to the one-child policy and other population control measures. As a result, it was far less than the worldwide level by $2005(0.32$ vs. 0.46$){ }^{2}$

By contrast, the old dependency ratio was somewhat lower than the worldwide level in 1975 (0.13 vs. 0.16) but has gradually increased due to the steady increases in life expectancy and was just under the worldwide level by 2005 (0.16 vs. 0.17).

However, because trends over time in the young dependency ratio have been more pronounced than trends over time in the old dependency ratio, trends in the total dependency ratio mirror trends in the youth dependency ratio: it was just over the worldwide level in 1975 (0.87 vs. 0.83) but declined sharply thereafter, falling to far less than the worldwide level by 2005 (0.48 vs. 0.63).

The fact that the young and total dependency ratios were formerly relatively high by international standards can explain why China's saving rate was formerly 
relatively low by international standards, and the fact that the young and total dependency ratios are now relatively low by international standards can explain why China’s saving rate is now relatively high by international standards.

Figure 2 shows data on trends over time in the saving rates of urban, rural, and all households for the 1995-2004 period from China's household survey, and as can be seen from this figure, the saving rates of the three categories of households are roughly comparable not only with respect to their levels but also with respect to trends over time therein. Looking first at the level of the saving rate, the saving rates of all three categories of households fluctuated in the 15.78-30.34\% range and the saving rates of urban, rural, and all households averaged 26.0\%, 26.5\%, and 25.5\%, respectively, during the 1995-2004 period (see Table 3). The close similarity in the levels of the saving rates of urban and rural households is very surprising since their income levels are so different and even widening, but it could be due to the greater income volatility of rural households, the vast majority of whom are farmers, as a result of which they save more for precautionary purposes, or to the fact that differences in income levels largely reflect differences in price levels, as a result of which the purchasing power of the incomes of urban and rural households is not nearly as different as their incomes per se.

Turning to trends over time in the saving rates of urban, rural, and all households, all three showed upward trends until 1999 before leveling off (except that the saving rate of urban households shows some evidence of an upward trend even after 1999). The upward trends in the saving rates of all three categories of households coincide with the downward trends in the young and total dependency ratios, and thus it is possible that the latter are one of the causes of the former. Thus, the evidence 
presented thus far suggests that the age structure of China's population can explain not only the high level of China's household saving rate but also the upward trend therein.

Table 1 shows data on the average saving rates of urban, rural, and all households during the 1995-2004 period by province, and as can be seen from this table, there has been enormous variation among provinces in their saving rates, with the saving rate of urban households ranging from $12.0 \%$ to $34.9 \%$, that of rural households ranging from $10.0 \%$ to $43.7 \%$, and that of all households ranging from $15.0 \%$ to $37.8 \%$.

Finally, Table 2 shows data on the age structure of urban, rural, and all households by province during the 1995-2004 period, and as can be seen from this table, there has been enormous variation among provinces in the age structure of their populations as well. For example, the young dependency ratio ranged from 0.17 to 0.39 for urban households, from 0.18 to 0.52 for rural households, and from 0.18 to 0.48 for all households, the old dependency ratio ranged from 0.07 to 0.18 for urban households, from 0.07 to 0.16 for rural households, and from 0.07 to 0.18 for all households, and the total dependency ratio ranged from 0.29 to 0.48 for urban households, from 0.34 to 0.66 for rural households, and from 0.31 to 0.56 for all households. We will conduct a regression analysis in sections 5 through 7 to see if variations in the household saving rate correlate with variations in the age structure of the population.

\section{The Estimation Model and Data Sources}

In this section, we discuss the estimation model and data sources we use in our empirical analysis.

The dependent variable we use in our analysis is SR = the household saving 
rate, defined as the ratio of household saving to household disposable income (net household income in the case of rural households) and where household saving is calculated as household disposable (or net) income minus household consumption.

Following Loayza, et al. (2000) and Schrooten and Stephan (2005), we estimate a reduced-form linear equation rather than adhering to a particular, narrow structural model, but the theoretical literature offers guidance regarding what variables should be included as explanatory variables. Since the life cycle hypothesis predicts that the household saving rate will be a function of the growth rate of per capita income and the age structure of the population (see, for example, Modigliani (1970) and Deaton (1992), Chapter 2), we include the following explanatory variables:

(1) $\mathrm{CHY}=$ the income growth rate, defined as the real rate of growth of per capita household disposable income (net household income in the case of rural households)

(2) YOUNG = the young dependency rate, defined as the ratio of the population aged 0-14 to the population aged 15-64 ${ }^{3}$

(3) OLD = the old dependency rate, defined as the ratio of the population aged 65 or older to the population aged 15-64

(4) DEP = the total dependency rate, defined as the ratio of the population aged $0-14$ or 65 or older to the population aged $15-64$

In addition, we include the following explanatory variables:

(5) $\mathrm{SR}(-1)=$ the one-year lag of the saving rate

(6) RINT = the real interest rate, defined as NINT - INFL, where NINT $=$ the nominal interest rate on one-year bank deposits and INFL = the rate of change of the 
consumer price index

(7) $\mathrm{INFL}=$ the rate of change of the consumer price index

(8) RURAL = a dummy variable that equals 1 in the case of rural households and zero otherwise (included only when the pooled sample of urban and rural households is used)

(9) A constant term

The lagged saving rate is included to test for the presence of inertia or persistence. The real interest rate is included to test for the impact of financial variables, and we would expect its coefficient to be positive if the substitution effect more than offsets the income effect. The inflation rate is included as a proxy for price uncertainty and/or macroeconomic stability more generally (as done by Loayza, et al. (2000) and Schrooten and Stephan (2005)), a rural dummy is included to see if there are any systematic differences between urban and rural households in trends over time in the household saving rate, and a constant term, which corresponds to the coefficient of the time trend in the regressions in differences (see section 6 below), is included in some variants

Finally, the real growth rate of per capita gross provincial product is used as an instrument in the level equation, as discussed below.

The data we use in our analysis are panel data for 1995-2004 on Chinese provinces. All variables are available for urban, rural, and all households with the exception of the nominal interest rate, which is available only for the country as a whole, and the real growth rate of per capita gross provincial product, which is available only for each province as a whole. Thus, we are able to obtain separate results for urban, 
rural, and all households and for a pooled sample of urban and rural households.

All data from China's household survey and national accounts data are taken from the China Statistics Yearbook, all demographic data are taken from the China Population Statistics Yearbook, and data on nominal interest rates are taken from the International Monetary Fund’s International Financial Statistics.

Data were available for all 31 provinces for the ten-year period from 1995 to 2004 with the following exceptions: data were not available for Chongqing Province during the 1995-96 period because this province did not become independent of Sichuan Province until 1997, and data on the CPI and/or on household income and consumption were not available for Tibet Province during the 1995-98 period. These missing values caused the number of observations to decline from 310 to 304 . Moreover, one year's worth of data were lost because the income growth rate was used as an explanatory variable. This reduced the number of observations further from 304 to 273 and means that the sample period for most provinces was nine years (1996-2004). Finally, because the lagged real growth rate of per capita gross provincial product was used as an instrument, yet another observation for Chongqing Province (that for 1998) had to be dropped, causing the final number of observations to be 272 .

Descriptive statistics on the variables used in our analysis for the final sample of 272 observations are shown in Table 3.

\section{Estimation Method}

In this section, we briefly describe our estimation method. Following Loayza, et al. (2000) and Schrooten and Stephan (2005), we use a generalized-method-of-moments (GMM) estimator applied to dynamic models using 
panel data. We use this estimator for at least three reasons: (1) Inertia is likely to be present in annual data, and it seemed desirable to use a dynamic specification to allow for it. (2) Some of the explanatory variables (such as RINT and CHY) are likely to be jointly determined with the saving rate, and it seemed desirable to control for the potential joint endogeneity of the explanatory variables. (3) There is the possibility of unobserved province-specific effects correlated with the regressors, and it seemed desirable to control for such effects.

Following Loayza, et al. (2000) and Schrooten and Stephan (2005), we use the alternative “system GMM estimator” proposed by Arellano and Bover (1995) and Blundell and Bond (1998), which reduces the potential biases and imprecision associated with the usual difference estimator by combining, in a system, the regression in differences with the regression in levels.

As Windmeijer (2005) notes, the estimated asymptotic standard errors of the efficient two-step GMM estimator will be severely downward biased in small samples, and thus we correct the standard errors for this bias using the method proposed by Windmeijer (2005). ${ }^{4}$

Following Loayza, et al. (2000) and Schrooten and Stephan (2005), the demographic variables (YOUNG, OLD, and DEP) are the only explanatory variables that we treated as being strictly exogenous and included as instruments in the level equation as well as the first-difference equation. All other explanatory variables were regarded as being weakly exogenous, and lagged values thereof were included as “internal instruments," with Bond's (2002) method being used to select instruments. ${ }^{5}$ Finally, the one-period lag of the real growth rate of per capita gross provincial product was used as an instrument only in the level equation. All of the instruments we use 
passed all of the commonly used tests: the Hansen test, the AR(1) test, and the $\operatorname{AR}(2)$ test. Tables 4-6 show the results of these tests and also show which instruments were used in each equation.

\section{Estimation Results}

In this section, we present our estimation results concerning the determinants of the household saving rate. The estimation results for urban, rural, and all households and for a pooled sample of urban and rural households are shown in Tables $4,5,6$, and 7, respectively.

Looking first at the coefficient of SR(-1) (the lagged saving rate), this coefficient is always positive and highly significant, indicating strong inertia or persistence. This coefficient ranges from 0.749 to 0.856 , implying a long-run effect that is 3.98 to 6.94 times the short-run effect; in the sample of urban households; from 0.721 to 0.844 , implying a long-run effect that is 3.58 to 6.41 times the short-run effect; in the sample of rural households; from 0.817 to 0.869 , implying a long-run effect that is 5.46 to 7.63 times the short-run effect, in the sample of all households, and from 0.737 to 0.867 , implying a long-run effect that is 3.80 to 7.52 times the short-run effect, in the pooled sample of urban and rural households.

Looking next at the coefficient of CHY (the income growth rate), it is always positive and highly significant (which is consistent with the life cycle hypothesis), ranging from 0.339 to 0.398 in the sample of urban households, from 0.482 to 0.536 in the sample of rural households, from 0.204 to 0.282 in the sample of all households, and from 0.371 to 0.534 in the pooled sample of urban and rural households. These figures imply that a one percentage point increase in the income growth rate causes a 0.20 to 
0.54 percentage point increase in the household saving rate. Moreover, the long-run impact of the income growth rate is 3.58 to 7.63 times these figures.

Looking next at the coefficient of RINT (the real interest rate), it is insignificant and usually negative in the sample of urban households, positive and significant in three out of four cases in the sample of rural households and in the sample of all households, and positive and significant in all cases in the case of the pooled sample of urban and rural households. Thus, the real interest rate has a significant positive impact on the household saving rate for every sample except for the sample of urban households, which suggests that the interest elasticity of saving is positive and is consistent with the permanent income hypothesis.

Looking next at the impact of the demographic variables (YOUNG, OLD, and DEP), the coefficient of YOUNG is totally insignificant in all four samples, and the coefficients of OLD and DEP are totally insignificant in all but one sample (with the exception of the coefficient of DEP being negative and significant in the pooled sample of urban and rural households with no constant term), and positive and significant in the sample of all households. Thus, the only case in which the coefficients of the demographic variables are significant with the expected sign is the case of the coefficient of DEP in the sample of pooled sample of urban and rural households with no constant term, and the coefficients of OLD and DEP are significant with the wrong sign in the sample of all households. Thus, the impact of the age structure of the population on the household saving rate in China is usually not significant with the expected sign and the direction of its impact is sometimes contrary to expectation, results which are unfavorable to the life cycle hypothesis. The reasons for the poor performance of the demographic variables is a topic for future research. ${ }^{6}$ 
Looking next at the coefficient of INFL (the inflation rate), it is insignificant in the sample of urban households and (with one exception) in the sample of rural households, negative and always significant in the sample of all households, and positive and significant half the time in the pooled sample of urban and rural households. These results suggest that the impact of inflation is unstable--sometimes insignificant, sometimes negative and significant, and sometimes positive and significant.

Looking next at the coefficient of the RURAL dummy in the pooled sample of urban and rural households, it is positive but significant in only one out of four cases, which suggests that there is no significant difference in trends over time in the saving rates of urban and rural households after controlling for other factors.

Looking finally at the constant term, which represents the coefficient of a time trend, it is positive in seven out of eight cases but is significant in only one case, which suggests that there is apparently no time trend in China's household saving rate.

We also tried adding year dummies and the level of per capita household disposable income as additional explanatory variables, but we dropped them from the final specification because their coefficients were not statistically significant.

Lastly, we compare our results to those of previous studies. Our finding that income growth has a positive and significant impact on the household saving rate is at variance with Kraay’s (2000) finding that (future) income growth has a negative and significant impact on the saving rate of rural households and does not have a significant impact on the saving rate of urban households but is consistent with Modigliani and Cao’s (2004) finding that (long run) income growth has a positive and significant impact on the household saving rate. In order to shed light on why our results differ from those of Kraay (2000), we tried estimating all of our equations using two-stage 
least squares, the same estimation method used by Kraay (2000), and found that the results are substantially different. For example, the coefficients of the variables relating to the age structure of the population, which had previously been insignificant, are now significant, whereas the coefficient of income growth, which had previously been positive and significant, becomes totally insignificant (which is consistent with Kraay's (2000) results for urban households) when two-stage least squares are used. These findings suggest that the differences between our results and those of Kraay (2000) are due largely to differences in estimation method and underscore the importance of using dynamic panel techniques when using panel data.

\section{Conclusion}

In this paper, we conducted a dynamic panel analysis of the determinants of the household saving rate in China using a life cycle model and panel data on Chinese provinces for the 1995-2004 period from China's household survey. To summarize our main findings, we found that China's household saving rate has been high and rising and that the main determinants of variations over time and over space therein are the lagged saving rate, the income growth rate, and (in some cases) the real interest rate and the inflation rate. However, we found that the variables relating to the age structure of the population usually do not have a significant impact on the household saving rate. These results provide mixed support for the life cycle hypothesis (with the positive and significant coefficient of income growth supporting the life cycle hypothesis and the mostly insignificant coefficients of the demographic variables being unfavorable to the life cycle hypothesis), provide some support for the permanent income hypothesis (with the positive and significant coefficient of the interest rate supporting this hypothesis), 
and are also consistent with the existence of inertia or persistence.

Turning to the implications of our findings, our finding that inertia or persistence are strong implies that there will not be a dramatic decline in China's household saving rate, and our finding that the income growth rate has a positive impact on the household saving rate implies that China's household saving rate will remain high as long as the growth rate remains high. However, if the growth rate tapers off, we can explain a gradual decline in the household saving rate.

Thus, it seems likely that China's household saving rate will remain high in the short to medium run, and to the extent that this causes China's current account surplus to remain high, this may cause continued frictions with the United States and China's other trading partners. In the long run, however, China's household saving rate can be expected to taper off assuming the growth rate tapers off, and thus, in the long run, China may well suffer from current account deficits rather than current account surpluses.

Turning finally to directions for further research, there are a number of factors that we were not able to consider in this analysis due to data limitations, such as borrowing constraints, precautionary saving, bequest motives, the distribution of income, and old-age pensions, health insurance, and other social insurance programs, and we hope to be able to incorporate these factors in our future research. 


\section{References}

Alessie, Rob, and Annamaria Lusardi. (1997) "Consumption, Saving and Habit Formation.” Economics Letters, 55:1 (August 15), 103-108.

Arellano, Manuel, and Stephen Bond. (1991) "Some Tests of Specification for Panel Data: Monte Carlo Evidence and an Application to Employment Equations.” Review of Economic Studies, 58:2 (April), 277-297.

Arellano, Manuel, and Olympia Bover. (1995) "Another Look at the Instrumental Variable Estimation of Error-Components Models." Journal of Econometrics, 68:1 (July), 29-51.

Banister, Judith. (1984) “An Analysis of Recent Data on the Population of China.” Population and Development Review, 10:2 (June), 241-271.

Banister, Judith. (1987) China's Changing Population. Stanford, California: Stanford University Press.

Blundell, Richard, and Stephen Bond. (1998) "Initial Conditions and Moment Restrictions in Dynamic Panel Data Models." Journal of Econometrics, 87:1 (August), 115-143.

Bond, Stephen. (2002) "Dynamic Panel Data Models: A Guide to Micro Data Methods and Practice." CEMMAP Working Paper CWP09/02, Department of Economics, Institute for Fiscal Studies, London.

Chamon, Marcos, and Eswar Prasad. (2006) "Determinants of Household Saving in China.” Mimeo., International Monetary Fund, Washington, D. C.

Deaton, Angus. (1992) Understanding Consumption. Oxford: Clarendon Press.

“The Frugal Giant.” The Economist, September 24-30, 2005, issue, pp. 12-14 of “A Survey of the World Economy.”

Kraay, Aart. (2000) “Household Saving in China.” World Bank Economic Review, 14:3 
(September), 545-570.

Kuijs, Louis. (2005) “Investment and Saving in China.” World Bank Policy Research Paper Series No. 3633 (June). Available at SSRN: http://ssrn.com/abstract=756985.

Kuijs, Louis. (2006) "How Will China's Saving-Investment Balance Evolve?" World Bank Policy Research Working Paper No. 3958 (July 1). Available at SSRN: http://ssrn.com/abstract=923265.

Loayza, Norman; Klaus Schmidt-Hebbel; and Luis Serven. (2000) "What Drives Private Saving across the World?” Review of Economics and Statistics, 82:2 (May), 165-181.

Modigliani, Franco. (1970) "The Life Cycle Hypothesis of Saving and Intercountry Differences in the Saving Ratio.” In Induction, Growth and Trade: Essays in Honour of Sir Roy Harrod, edited by W. A. Eltis, M. FG. Scott, and J. N. Wolfe, pp. 197-225. Oxford: Clarendon Press.

Modigliani, Franco, and Shi Larry Cao. (2004) "The Chinese Saving Puzzle and the Life-Cycle Hypothesis.” Journal of Economic Literature, 42:1 (March), 145-170.

Roodman, D. (2005) “ xtabond2: Stata module to extend xtabond dynamic panel data estimator.” Center for Global Development, Washington, D.C. http://econpapers.repec.org/software/bocbocode/s435901.htm

Schrooten, Mechthild, and Sabine Stephan. (2005) "Private Savings and Transition: Dynamic Panel Data Evidence from Accession Countries.” Economics of Transition, 13:2, 287-309.

Windmeijer, Frank. (2005) “A Finite Sample Correction for the Variance of Linear Efficient Two-Step GMM Estimators.” Journal of Econometrics, 126:1 (May), 25-51.

\section{Data Sources}

Central Intelligence Agency, CIA World Factbook. http://www.indexmundi. $\mathrm{com} / \mathrm{g} / \mathrm{g} \cdot \operatorname{aspx} ? \mathrm{c}=\mathrm{ch} \& \mathrm{v}=30$ 
Department of Population, Social, Science and Technology Statistics, National Bureau of Statistics of China, ed., China Population Statistics Yearbook, 1991-2005 editions. Beijing: China Statistics Press.

International Monetary Fund , International Financial Statistics, 1995-2005.

National Bureau of Statistics of China., ed., China Statistical Yearbook, 1988-2005 editions. Beijing: China Statistics Press.

United Nations (2002), World Population Prospects: The 2002 Revision. New York: United Nations. 
Figure 1: Age Structure of the Population in China, 1949- 2004

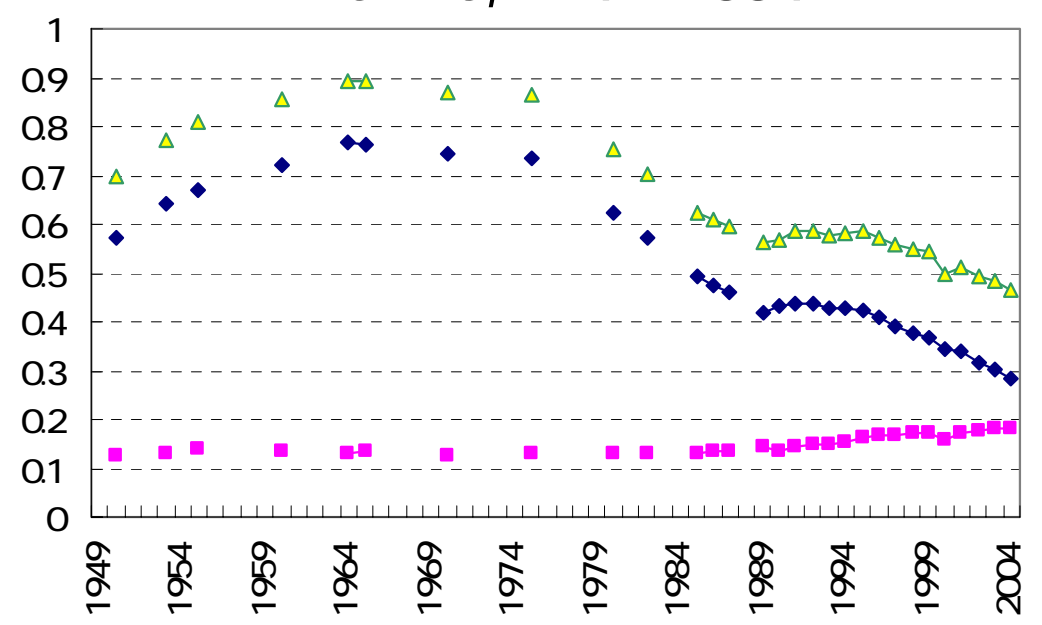

Sources: China Population Statistics Yearbook, 1988- 2005 editions, and World Population Prospects: The 2002 Revision (United Nations)

$\rightarrow$ Ratio of the
population
aged 0-14 to
the population
aged 15-59


- Ratio of the
population
aged 60 or
older to the
population
aged 15- 59
$\rightarrow$ Ratio of the
population
aged 0-14 or
60 or older to
the population
aged 15- 59


Figure 2: Household Saving Rate in China, 1995- 2004
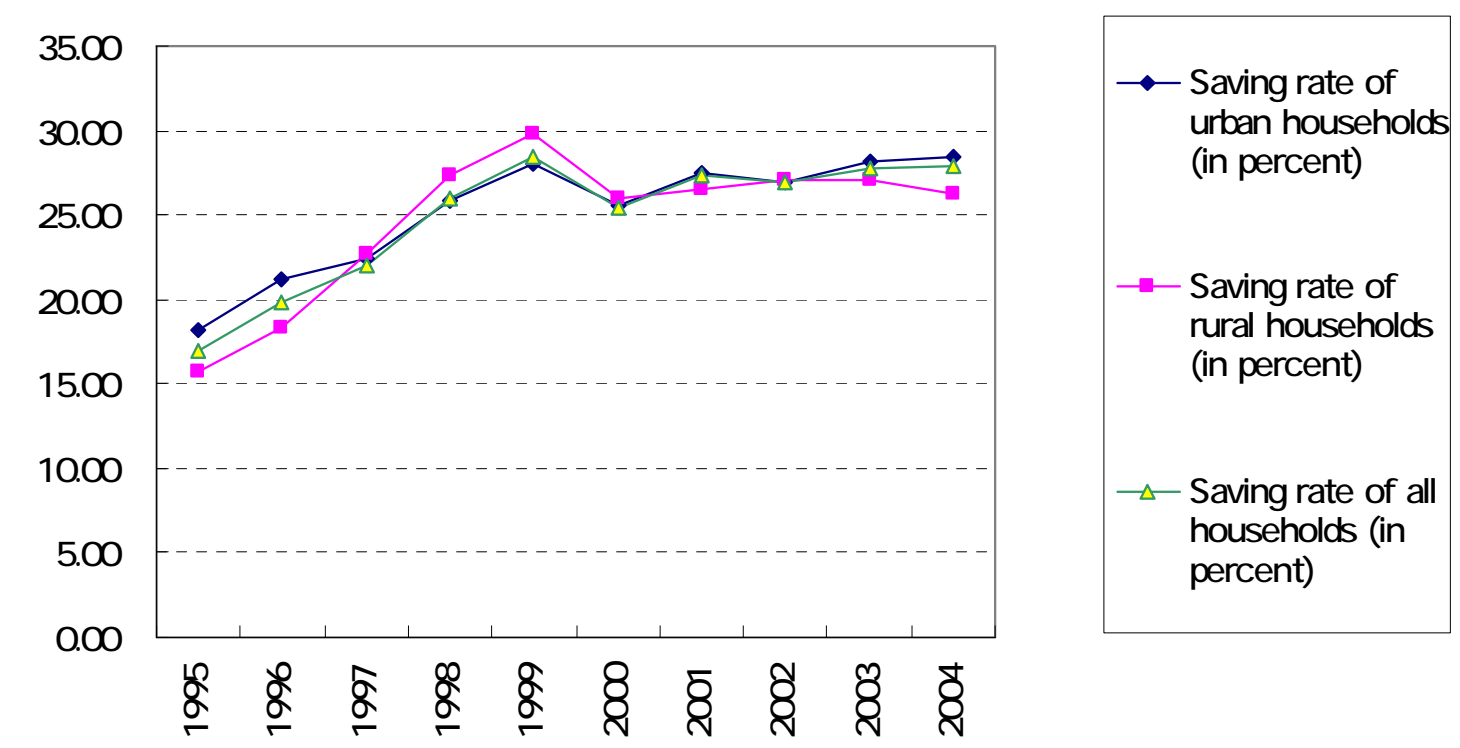

Source: Authors' calculations based on China Statistics Yearbook, 1996-

2005 editions 


\section{Table 1: Household Saving Rate by Province (Averages for the 1995-2004 Period)}

\begin{tabular}{|c|c|c|c|}
\hline \multirow{2}{*}{ Province } & \multicolumn{3}{|c|}{ Saving rate (in percent) } \\
\hline & Urban households & Rural households & All households \\
\hline Beijing & 24.2 & 27.2 & 24.7 \\
\hline Tianjin & 28.9 & 43.7 & 32.6 \\
\hline Hebei & 30.9 & 41.7 & 37.8 \\
\hline Shanxi & 28.1 & 35.5 & 32.0 \\
\hline Inner Mongolia & 29.4 & 17.4 & 24.2 \\
\hline Liaoning & 21.4 & 29.0 & 24.0 \\
\hline Jilin & 24.0 & 27.7 & 25.4 \\
\hline Heilongiiang & 29.3 & 31.1 & 30.0 \\
\hline Shanghai & 29.1 & 19.6 & 27.9 \\
\hline J iangsu & 30.9 & 31.0 & 31.0 \\
\hline Zhejiang & 28.4 & 23.3 & 25.6 \\
\hline Anhui & 26.9 & 26.7 & 26.8 \\
\hline Fujian & 30.0 & 26.1 & 28.4 \\
\hline J iangxi & 34.9 & 22.6 & 27.9 \\
\hline Shandong & 32.7 & 30.3 & 31.5 \\
\hline Henan & 29.9 & 31.9 & 31.4 \\
\hline Hubei & 20.5 & 24.9 & 22.7 \\
\hline Hunan & 22.8 & 10.4 & 15.5 \\
\hline Guangdong & 24.2 & 24.8 & 24.4 \\
\hline Guangxi & 24.8 & 20.8 & 22.8 \\
\hline Hainan & 29.5 & 34.5 & 32.1 \\
\hline Chongqing & 12.0 & 24.4 & 18.3 \\
\hline Sichuan & 20.0 & 18.2 & 18.9 \\
\hline Guizhou & 25.1 & 20.3 & 22.2 \\
\hline Yunnan & 24.3 & 10.0 & 16.3 \\
\hline Tibet & 24.9 & 31.2 & 27.8 \\
\hline Shaanxi & 19.0 & 10.9 & 15.0 \\
\hline Gansu & 22.4 & 21.0 & 21.5 \\
\hline Qinghai & 21.9 & 16.1 & 19.5 \\
\hline Ningxia & 20.5 & 17.8 & 19.2 \\
\hline Xinjiang & 29.1 & 16.6 & 25.7 \\
\hline
\end{tabular}

Source: Authors' calculations based on China Statistics Yearbook, 1996- 2005 editions, and China Population Statistics Yearbook, 1996- 2005 editions. 


\section{Table 2: Age Structure of the Population by Province (Averages for the 1995-2004 Period)}

\begin{tabular}{|c|c|c|c|c|c|c|c|c|c|}
\hline \multirow[b]{2}{*}{ Province } & \multicolumn{3}{|c|}{ Urban households } & \multicolumn{3}{|c|}{ Rural households } & \multicolumn{3}{|c|}{ All households } \\
\hline & $\begin{array}{l}\text { Young } \\
\text { dependency } \\
\text { ratio }\end{array}$ & $\begin{array}{l}\text { Old } \\
\text { dependency } \\
\text { ratio }\end{array}$ & $\begin{array}{l}\text { Total } \\
\text { dependency } \\
\text { ratio }\end{array}$ & $\begin{array}{l}\text { Young } \\
\text { dependency } \\
\text { ratio }\end{array}$ & $\begin{array}{l}\text { Old } \\
\text { dependency } \\
\text { ratio }\end{array}$ & $\begin{array}{l}\text { Total } \\
\text { dependency } \\
\text { ratio }\end{array}$ & $\begin{array}{c}\text { Young } \\
\text { dependency } \\
\text { ratio }\end{array}$ & $\begin{array}{l}\text { Old } \\
\text { dependency } \\
\text { ratio }\end{array}$ & $\begin{array}{c}\text { Total } \\
\text { dependency } \\
\text { ratio }\end{array}$ \\
\hline Beijing & 0.167 & 0.123 & 0.290 & 0.276 & 0.125 & 0.401 & 0.188 & 0.123 & 0.311 \\
\hline Tianjin & 0.204 & 0.136 & 0.340 & 0.338 & 0.109 & 0.447 & 0.245 & 0.127 & 0.372 \\
\hline Hebei & 0.264 & 0.092 & 0.357 & 0.355 & 0.104 & 0.459 & 0.333 & 0.101 & 0.435 \\
\hline Shanxi & 0.304 & 0.088 & 0.392 & 0.419 & 0.101 & 0.519 & 0.378 & 0.096 & 0.474 \\
\hline $\begin{array}{l}\text { Inner } \\
\text { Mongolia }\end{array}$ & 0.269 & 0.078 & 0.347 & 0.326 & 0.088 & 0.414 & 0.303 & 0.084 & 0.387 \\
\hline Liaoning & 0.207 & 0.119 & 0.325 & 0.278 & 0.098 & 0.375 & 0.239 & 0.109 & 0.349 \\
\hline Jilin & 0.216 & 0.094 & 0.310 & 0.280 & 0.078 & 0.357 & 0.248 & 0.086 & 0.333 \\
\hline Heilongjiang & 0.227 & 0.080 & 0.308 & 0.291 & 0.068 & 0.359 & 0.257 & 0.075 & 0.332 \\
\hline Shanghai & 0.175 & 0.185 & 0.360 & 0.182 & 0.160 & 0.341 & 0.176 & 0.181 & 0.357 \\
\hline J iangsu & 0.236 & 0.122 & 0.358 & 0.328 & 0.158 & 0.486 & 0.287 & 0.138 & 0.425 \\
\hline Zhejiang & 0.223 & 0.123 & 0.347 & 0.278 & 0.145 & 0.423 & 0.255 & 0.135 & 0.390 \\
\hline Anhui & 0.300 & 0.107 & 0.407 & 0.396 & 0.115 & 0.511 & 0.369 & 0.112 & 0.481 \\
\hline Fujian & 0.272 & 0.103 & 0.375 & 0.427 & 0.119 & 0.546 & 0.368 & 0.110 & 0.479 \\
\hline J iangxi & 0.303 & 0.099 & 0.402 & 0.428 & 0.101 & 0.529 & 0.388 & 0.100 & 0.488 \\
\hline Shandong & 0.265 & 0.100 & 0.365 & 0.321 & 0.130 & 0.450 & 0.299 & 0.117 & 0.417 \\
\hline Henan & 0.290 & 0.098 & 0.388 & 0.407 & 0.110 & 0.518 & 0.381 & 0.108 & 0.488 \\
\hline Hubei & 0.266 & 0.092 & 0.358 & 0.409 & 0.111 & 0.520 & 0.353 & 0.103 & 0.456 \\
\hline Hunan & 0.257 & 0.109 & 0.366 & 0.360 & 0.117 & 0.477 & 0.330 & 0.114 & 0.444 \\
\hline Guangdong & 0.315 & 0.098 & 0.412 & 0.525 & 0.134 & 0.659 & 0.429 & 0.116 & 0.545 \\
\hline Guangxi & 0.290 & 0.120 & 0.410 & 0.427 & 0.118 & 0.545 & 0.393 & 0.118 & 0.511 \\
\hline Hainan & 0.342 & 0.080 & 0.422 & 0.486 & 0.121 & 0.607 & 0.436 & 0.106 & 0.542 \\
\hline Chongqing & 0.231 & 0.133 & 0.364 & 0.356 & 0.127 & 0.483 & 0.305 & 0.129 & 0.435 \\
\hline Sichuan & 0.255 & 0.129 & 0.384 & 0.355 & 0.110 & 0.465 & 0.321 & 0.117 & 0.437 \\
\hline Guizhou & 0.313 & 0.101 & 0.414 & 0.479 & 0.092 & 0.572 & 0.431 & 0.095 & 0.526 \\
\hline Yunnan & 0.270 & 0.111 & 0.381 & 0.423 & 0.095 & 0.518 & 0.391 & 0.098 & 0.490 \\
\hline Tibet & 0.389 & 0.093 & 0.481 & 0.497 & 0.083 & 0.580 & 0.479 & 0.086 & 0.565 \\
\hline Shaanxi & 0.280 & 0.107 & 0.387 & 0.412 & 0.095 & 0.507 & 0.371 & 0.099 & 0.470 \\
\hline Gansu & 0.247 & 0.090 & 0.337 & 0.433 & 0.078 & 0.511 & 0.383 & 0.081 & 0.465 \\
\hline Qinghai & 0.265 & 0.077 & 0.342 & 0.460 & 0.069 & 0.529 & 0.394 & 0.072 & 0.466 \\
\hline Ningxia & 0.276 & 0.071 & 0.347 & 0.509 & 0.068 & 0.577 & 0.427 & 0.069 & 0.496 \\
\hline Xinjiang & 0.282 & 0.075 & 0.357 & 0.494 & 0.074 & 0.568 & 0.402 & 0.075 & 0.477 \\
\hline
\end{tabular}

Notes: The young dependency ratio is defined as the ratio of the population aged $0-14$ to the population aged 15-64; The old dependency ratio is defined as the ratio of the population aged 65 or older to the population aged 15-64; The total dependency ratio is defined as the ratio of the population aged $0-14$ or 65 or older to the population aged 15- 64 .

Source: Authors' calculations based on China Population Statistics Yearbook, 1996- 2005 editions. 


\section{Table 3: Descriptive Statistics}

\begin{tabular}{lccccc}
\hline Variable & Obs & Mean & Std. Dev. & Min & Max \\
\hline SR (all) & 272 & 0.260 & 0.066 & 0.096 & 0.416 \\
SR (urban) & 272 & 0.265 & 0.066 & 0.083 & 0.455 \\
SR (rural) & 272 & 0.255 & 0.097 & -0.044 & 0.494 \\
YOUNG (all) & 272 & 0.312 & 0.086 & 0.116 & 0.527 \\
YOUNG (urban) & 272 & 0.257 & 0.053 & 0.110 & 0.420 \\
YOUNG (rural) & 272 & 0.376 & 0.093 & 0.136 & 0.596 \\
OLD (all) & 272 & 0.102 & 0.027 & 0.043 & 0.219 \\
OLD (urban) & 272 & 0.106 & 0.028 & 0.027 & 0.225 \\
OLD (rural) & 272 & 0.108 & 0.029 & 0.063 & 0.314 \\
DEP (all) & 272 & 0.414 & 0.084 & 0.220 & 0.655 \\
DEP (urban) & 272 & 0.363 & 0.048 & 0.245 & 0.539 \\
DEP (rural) & 272 & 0.483 & 0.088 & 0.262 & 0.771 \\
NINT (all) & 272 & 0.033 & 0.018 & 0.020 & 0.075 \\
INFL (all) & 272 & 0.017 & 0.031 & -0.033 & 0.116 \\
INFL (urban) & 272 & 0.016 & 0.032 & -0.034 & 0.116 \\
INFL (rural) & 272 & 0.017 & 0.031 & -0.037 & 0.116 \\
RINT (all) & 272 & 0.016 & 0.022 & -0.041 & 0.068 \\
RINT (urban) & 272 & 0.016 & 0.022 & -0.041 & 0.067 \\
RINT (rural) & 272 & 0.015 & 0.024 & -0.041 & 0.072 \\
CHGDP (all) & 272 & 0.094 & 0.050 & -0.272 & 0.228 \\
POP & 272 & 4126.225 & 2601.504 & 262.000 & 11430.000 \\
CHPOP & 272 & 8.613 & 18.023 & -49.865 & 188.721 \\
INCOME (all) & 272 & 3844.672 & 2097.599 & 1511.344 & 14573.670 \\
INCOME (urban) & 272 & 6643.530 & 2341.563 & 3353.940 & 16682.820 \\
INCOME (rural) & 272 & 2521.854 & 1126.045 & 1100.590 & 7066.330 \\
CONS (all) & 272 & 2938.318 & 1591.129 & 1323.966 & 11248.800 \\
CONS (urban) & 272 & 5239.805 & 1771.079 & 2767.840 & 12631.030 \\
CONS (rural) & 272 & 1848.667 & 839.803 & 880.650 & 6328.849 \\
RURALRATIO & 272 & 0.692 & 0.151 & 0.219 & 0.864 \\
CPI (all) & 272 & 101.663 & 3.081 & 96.700 & 111.600 \\
CPI (urban) & 272 & 101.645 & 3.168 & 96.600 & 111.600 \\
CPI (rural) & 272 & 101.736 & 3.078 & 96.300 & 111.600 \\
CHY(all) & 272 & 0.073 & 0.034 & -0.037 & 0.191 \\
CHY(urban) & 272 & 0.073 & 0.042 & -0.039 & 0.231 \\
CHY(rural) & 272 & 0.060 & 0.052 & -0.101 & 0.331 \\
\hline SOurce:Auth & & & & \\
\hline
\end{tabular}

Source: Authors' calculations based on China Statistics Yearbook, 1996- 2005 editions, China Population Statistics Yearbook, 1996- 2005 editions, and International Financial Statistics, 1995- 2005 editions. 
Table 4: The Determinants of the Household Saving Rate in China (Urban Households)

\begin{tabular}{|c|c|c|c|c|}
\hline \multirow[b]{2}{*}{$\mathrm{SR}(-1)$} & \multicolumn{4}{|c|}{ Dependent variable $=\mathrm{SR}$} \\
\hline & 0.856 & 0.817 & 0.783 & 0.749 \\
\hline & $(0.063)^{* * *}$ & $(0.082)^{* * *}$ & $(0.088)^{* * *}$ & $(0.092)^{* * *}$ \\
\hline \multirow[t]{2}{*}{$\mathrm{CHY}$} & 0.365 & 0.398 & 0.339 & 0.341 \\
\hline & $(0.145)^{* *}$ & $(0.169)^{* *}$ & $(0.160)^{* *}$ & $(0.145)^{* *}$ \\
\hline \multirow[t]{2}{*}{ RINT } & 0.131 & -0.119 & -0.102 & -0.118 \\
\hline & $(0.460)$ & (0.576) & (0.383) & (0.353) \\
\hline \multirow[t]{2}{*}{ YOUNG } & 0.039 & & 0.021 & \\
\hline & (0.095) & & (0.094) & \\
\hline \multirow[t]{2}{*}{ OLD } & 0.034 & & -0.040 & \\
\hline & $(0.113)$ & & (0.114) & \\
\hline \multirow[t]{2}{*}{ DEP } & & 0.076 & & -0.001 \\
\hline & & $(0.120)$ & & (0.085) \\
\hline \multirow[t]{2}{*}{ INFL } & 0.290 & 0.149 & 0.126 & 0.116 \\
\hline & (0.305) & (0.381) & $(0.266)$ & $(0.245)$ \\
\hline \multirow[t]{2}{*}{ Constant } & & & 0.039 & 0.049 \\
\hline & & & $(0.041)$ & $(0.040)$ \\
\hline Observations & 272 & 272 & 272 & 272 \\
\hline Number of groups & 31 & 31 & 31 & 31 \\
\hline Hansen test of overidentification ( $p$-value) & 0.297 & 0.485 & 0.517 & 0.665 \\
\hline Test for 1st- order serial correlation ( $p$ - value) & 0.000 & 0.000 & 0.000 & 0.001 \\
\hline \multirow{2}{*}{$\begin{array}{l}\text { Test for } 2 \text { st- order serial correlation ( } p \text {-value) } \\
\text { Transformation used }\end{array}$} & 0.118 & 0.166 & 0.11 & 0.114 \\
\hline & \multicolumn{4}{|c|}{ first differences } \\
\hline Instruments only for first difference equation & $\begin{array}{l}\text { GMM(SR(- 1), CHY, RINT, } \\
\text { INFL, }(2,5)) \\
\end{array}$ & $\begin{array}{l}\mathrm{GMM}(\mathrm{SR}(-1), \mathrm{CHY}, \\
\mathrm{RINT}, \mathrm{INFL},(2,4)) \\
\end{array}$ & $\begin{array}{l}\text { GMM(SR(- 1), CHY, } \\
\text { RINT, INFL, }(2,4))\end{array}$ & $\begin{array}{l}\text { GMM(SR(- 1), CHY, } \\
\text { RINT, INFL, (2, 4)) }\end{array}$ \\
\hline \multirow{2}{*}{$\begin{array}{l}\text { Instruments for both first difference and level } \\
\text { equations } \\
\text { Instruments only for level equation }\end{array}$} & YOUNG, OLD & DEP & YOUNG, OLD & DEP \\
\hline & \multicolumn{4}{|c|}{ CHGDP(- 1) } \\
\hline
\end{tabular}


Table 5: The Determinants of the Household Saving Rate in China (Rural Households)

\begin{tabular}{|c|c|c|c|c|}
\hline \multirow[b]{2}{*}{$\mathrm{SR}(-1)$} & \multicolumn{4}{|c|}{ Dependent variable $=\mathrm{SR}$} \\
\hline & 0.774 & 0.844 & 0.811 & 0.721 \\
\hline & $(0.068)^{* * *}$ & $(0.042)^{* * *}$ & $(0.075)^{* * *}$ & $(0.122)^{* * *}$ \\
\hline \multirow[t]{2}{*}{$\mathrm{CHY}$} & 0.495 & 0.536 & 0.482 & 0.487 \\
\hline & $(0.107)^{* * *}$ & $(0.149)^{* * *}$ & $(0.130)^{* * *}$ & $(0.163)^{* * *}$ \\
\hline \multirow[t]{2}{*}{ RINT } & 0.591 & 0.593 & 0.436 & 0.425 \\
\hline & $(0.163)^{* * *}$ & $(0.185)^{* * *}$ & $(0.205)^{* *}$ & $(0.255)$ \\
\hline \multirow[t]{2}{*}{ YOUNG } & 0.030 & & -0.032 & \\
\hline & $(0.033)$ & & (0.051) & \\
\hline \multirow[t]{2}{*}{ OLD } & 0.200 & & -0.089 & \\
\hline & $(0.157)$ & & $(0.172)$ & \\
\hline \multirow[t]{2}{*}{ DEP } & & 0.025 & & -0.069 \\
\hline & & (0.024) & & (0.054) \\
\hline \multirow[t]{2}{*}{ INFL } & -0.356 & -0.338 & -0.360 & -0.467 \\
\hline & $(0.180)^{*}$ & $(0.232)$ & $(0.226)$ & $(0.332)$ \\
\hline Constant & & & $\begin{array}{c}0.049 \\
(0.029)\end{array}$ & $\begin{array}{c}0.083 \\
(0.051)\end{array}$ \\
\hline Observations & 272 & 272 & 272 & 272 \\
\hline Number of groups & 31 & 31 & 31 & 31 \\
\hline Hansen test of overidentification ( $p$ - value) & 0.286 & 0.285 & 0.324 & 0.341 \\
\hline Test for 1st- order serial correlation ( $p$ - value) & 0.000 & 0.000 & 0.000 & 0.001 \\
\hline \multirow{2}{*}{$\begin{array}{l}\text { Test for } 2 \text { st- order serial correlation ( } p \text {-value) } \\
\text { Transformation used }\end{array}$} & 0.680 & 0.802 & 0.724 & 0.835 \\
\hline & \multicolumn{4}{|c|}{ first differences } \\
\hline \multirow{3}{*}{$\begin{array}{l}\text { Instruments only for first difference equation } \\
\text { Instruments for both first difference and level } \\
\text { equations } \\
\text { Instruments only for level equation }\end{array}$} & $\begin{array}{l}\text { GMM(SR(- 1), CHY, RINT, } \\
\text { INFL, (2 .) collapse) } \\
\end{array}$ & $\begin{array}{l}\text { GMM(SR(- 1), CHY, RINT, } \\
\text { INFL, (2 .) collapse) }\end{array}$ & $\begin{array}{l}\text { GMM(SR(- 1), CHY, } \\
\text { RINT, INFL, (2, 4)) }\end{array}$ & $\begin{array}{l}\text { GMM(SR(- 1), CHY, } \\
\text { RINT, INFL, (2, 3)) }\end{array}$ \\
\hline & YOUNG, OLD & DEP & YOUNG, OLD & DEP \\
\hline & \multicolumn{4}{|c|}{ CHGDP(-1) } \\
\hline
\end{tabular}


Table 6: The Determinants of the Household Saving Rate in China (All Households)

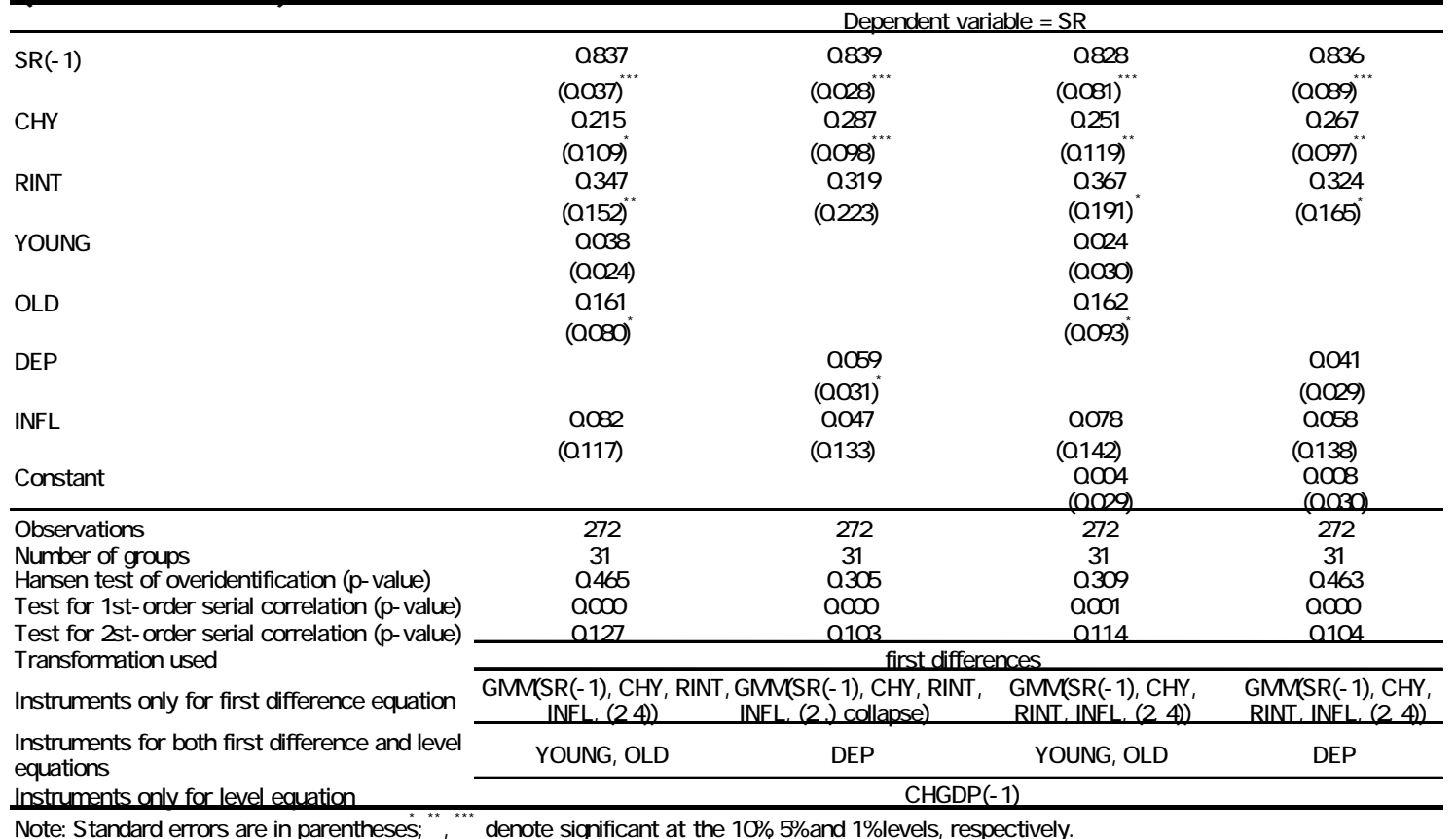


Table 7: The Determinants of the Household Saving Rate in China (Pooled Sample of Both Urban and Rural Households)

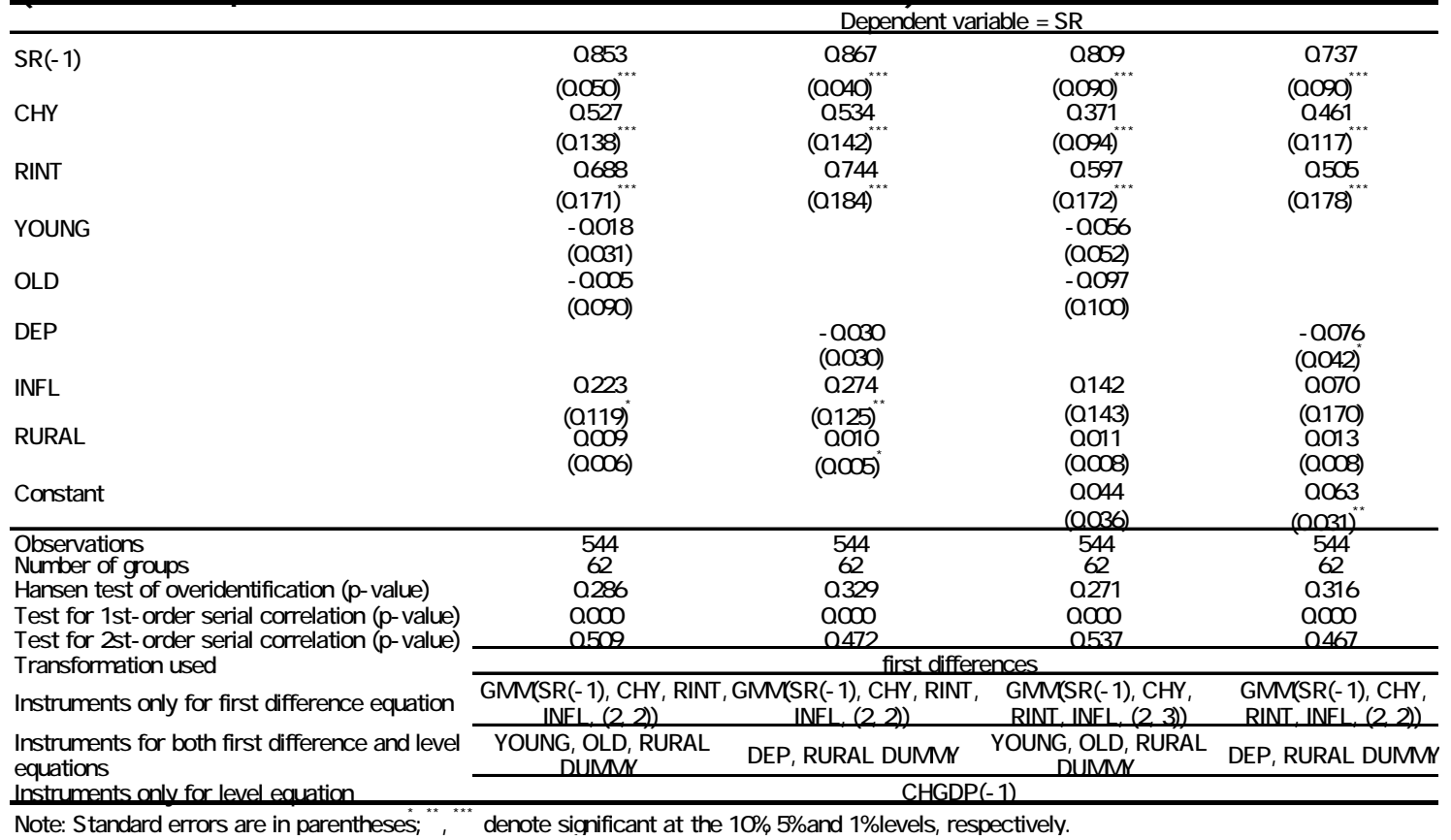


Data Appendix for Figure 1 and Other Related Variables

\begin{tabular}{|c|c|c|c|c|c|}
\hline Year & $\begin{array}{c}\text { Young Dependency } \\
\text { Ratio }\end{array}$ & $\begin{array}{c}\text { Old Dependency } \\
\text { Ratio }\end{array}$ & $\begin{array}{c}\text { Total Dependency } \\
\text { Ratio }\end{array}$ & $\begin{array}{l}\text { Life expectancy at } \\
\text { birth (in years) }\end{array}$ & $\begin{array}{l}\text { Total population (in } \\
\text { millions) }\end{array}$ \\
\hline 1949 & \multirow{4}{*}{0.57} & \multirow{4}{*}{0.13} & \multirow{4}{*}{0.70} & \multirow{4}{*}{40.80} & 541.67 \\
\hline 1950 & & & & & 551.96 \\
\hline 1951 & & & & & 563.00 \\
\hline 1952 & & & & & 574.82 \\
\hline 1953 & \multirow{2}{*}{0.64} & \multirow{2}{*}{0.13} & \multirow{2}{*}{0.77} & 40.30 & 587.96 \\
\hline 1954 & & & & 42.40 & 602.66 \\
\hline 1955 & \multirow{5}{*}{0.67} & \multirow[t]{5}{*}{0.14} & \multirow[t]{5}{*}{0.81} & 44.60 & 614.65 \\
\hline 1956 & & & & 47.00 & 628.28 \\
\hline 1957 & & & & 49.50 & 646.53 \\
\hline 1958 & & & & 45.80 & 659.94 \\
\hline 1959 & & & & 42.50 & 672.07 \\
\hline 1960 & \multirow{4}{*}{0.72} & \multirow{4}{*}{0.13} & \multirow{4}{*}{0.86} & 24.60 & 662.07 \\
\hline 1961 & & & & 38.40 & 658.59 \\
\hline 1962 & & & & 53.00 & 672.95 \\
\hline 1963 & & & & 54.90 & 691.72 \\
\hline 1964 & 0.77 & 0.13 & 0.89 & 57.10 & 704.99 \\
\hline 1965 & \multirow[t]{5}{*}{0.76} & \multirow[t]{5}{*}{0.13} & \multirow[t]{5}{*}{0.89} & 57.80 & 725.38 \\
\hline 1966 & & & & 58.60 & 745.42 \\
\hline 1967 & & & & 59.40 & 763.68 \\
\hline 1968 & & & & 60.30 & 785.34 \\
\hline 1969 & & & & 60.80 & 806.71 \\
\hline 1970 & \multirow[t]{5}{*}{0.74} & \multirow[t]{5}{*}{0.13} & 0.87 & 61.40 & 829.92 \\
\hline 1971 & & & & 62.00 & 852.29 \\
\hline 1972 & & & & 62.30 & 871.77 \\
\hline 1973 & & & & 63.00 & 892.11 \\
\hline 1974 & & & & 63.40 & 908.59 \\
\hline 1975 & 0.74 & 0.13 & 0.87 & 63.80 & 924.20 \\
\hline 1976 & & & & 64.20 & 937.17 \\
\hline 1977 & & & & 64.60 & 949.74 \\
\hline 1978 & & & & 65.10 & 962.59 \\
\hline 1979 & & & & 65.00 & 975.42 \\
\hline 1980 & 0.62 & 0.13 & 0.75 & 64.90 & 987.05 \\
\hline 1981 & & & & 64.80 & 1000.72 \\
\hline 1982 & 0.57 & 0.13 & 0.70 & 64.70 & 1016.54 \\
\hline 1983 & & & & 64.63 & 1030.08 \\
\hline 1984 & & & & 64.55 & 1043.57 \\
\hline 1985 & 0.49 & 0.13 & 0.62 & 66.60 & 1058.51 \\
\hline 1986 & 0.47 & 0.13 & 0.61 & & 1075.07 \\
\hline 1987 & 0.46 & 0.14 & 0.59 & & 1093.00 \\
\hline 1988 & & & & & 1110.26 \\
\hline 1989 & 0.42 & 0.14 & 0.56 & & 1127.04 \\
\hline 1990 & 0.43 & 0.13 & 0.57 & 68.55 & 1143.33 \\
\hline 1991 & 0.44 & 0.15 & 0.59 & & 1158.23 \\
\hline 1992 & 0.44 & 0.15 & 0.59 & & 1171.71 \\
\hline 1993 & 0.43 & 0.15 & 0.58 & & 1185.17 \\
\hline 1994 & 0.43 & 0.15 & 0.58 & & 1198.50 \\
\hline 1995 & 0.42 & 0.16 & 0.58 & 69.70 & 1211.21 \\
\hline 1996 & 0.41 & 0.17 & 0.57 & & 1223.89 \\
\hline 1997 & 0.39 & 0.17 & 0.56 & & 1236.26 \\
\hline 1998 & 0.38 & 0.17 & 0.55 & & 1247.61 \\
\hline 1999 & 0.37 & 0.17 & 0.54 & & 1257.86 \\
\hline 2000 & 0.34 & 0.16 & 0.50 & 71.38 & 1267.43 \\
\hline 2001 & 0.34 & 0.17 & 0.51 & 71.62 & 1276.27 \\
\hline 2002 & 0.32 & 0.18 & 0.49 & 71.86 & 1284.53 \\
\hline 2003 & 0.30 & 0.18 & 0.48 & 72.22 & 1292.27 \\
\hline 2004 & 0.28 & 0.18 & 0.46 & 71.96 & 1299.88 \\
\hline
\end{tabular}

Note: Young Dependency Ratio is defined as the ratio of the population aged 0-14 to the population aged 15-59; Old Dependency Ratio is defined as the ratio of the population aged 60 or older to the population aged 15-59; Total Dependency Ratio is defined as the ratio of the population aged 0-14 or 60 or older to the population aged 15-59.

Sources: China Population Statistics Yearbook, 1988 2005 editions; Banister (1987); World Population Prospects: The 2002 Revision (United Nations); and U.S. CIA Factbook. 
Data Appendix for Figure 2

\begin{tabular}{cccc}
\hline Year & $\begin{array}{c}\text { Saving rate of urban } \\
\text { households (in } \\
\text { percent) }\end{array}$ & $\begin{array}{c}\text { Saving rate of rural } \\
\text { households (in percent) }\end{array}$ & $\begin{array}{c}\text { Saving rate of all } \\
\text { households (in percent) }\end{array}$ \\
\hline 1995 & 21.08 & 15.78 & 18.18 \\
1996 & 24.01 & 18.38 & 21.15 \\
1997 & 22.32 & 22.65 & 22.40 \\
1998 & 24.67 & 27.30 & 25.90 \\
1999 & 26.22 & 29.77 & 28.02 \\
2000 & 25.09 & 25.93 & 25.52 \\
2001 & 28.29 & 26.51 & 27.53 \\
2002 & 27.25 & 27.12 & 26.97 \\
2003 & 29.17 & 27.11 & 28.13 \\
2004 & 30.34 & 26.29 & 28.44 \\
\hline
\end{tabular}

Source: Authors' calculations based on China Statistics Yearbook, 1996- 2005 editions. 


\section{Endnotes}

1 See Kuijs (2005, 2006) for data on the overall level and sectoral composition of saving and investment and on the saving-investment balance in China.

2 The demographic data in this paragraph and the two following paragraphs are based on United Nations data and hence do not coincide precisely with the earlier data.

3 It would have been preferable to use the population aged 15-59 since the retirement age in China (for males) is 60, but we could not do so due to data limitations.

4 All calculations were done using Stata, version 9.2. We used Roodman's (2005) "xtabond2" program in Stata to correct the standard errors.

5 The "collapse" command in Stata was used to select instruments.

6 Chamon and Prasad (2006) analyze micro data from the same household survey we use and find that saving increases with age and is highest for the elderly. This can explain why the coefficients of OLD and DEP are often positive and sometimes even significant. 